\title{
Manajemen Redaksional \\ Pada Surat Kabar Harian Umum Radar Cirebon \\ (Studi Deskriptif Kualitatif Manajemen Redaksional pada Surat Kabar Harian Umum Radar Cirebon Periode Januari-Mei \\ 2013)
}

\author{
M. Irfan Fazryansyah, Heriyani Agustina, dan Nuruzzaman
}

\author{
Universitas Swadaya Gunung Jati Cirebon Jl. Pemuda No. 32, Cirebon, Jawa Barat 45132 \\ No. Telp (0231) 236742 \\ Email: irfanfazryansah@ymail.com
}

\begin{abstract}
Mass media after the era of reform becomes the mass communication facility and instrument shaper of public opinion, it is helping in human life to exchanging ideas, sharing of experience and information in the volume of a relatively large. This research aims to understand planning, organizing, mobilizing and supervision in the management of editorial on daily newspaper of Radar Cirebon. A method of this research is descriptive qualitative, data was gathered by direct interview, observasion and availability of literature studies. Based on covered can be drawn conclusions that ( 1 ) In the planning stages, daily newspaper of Radar Cirebon well to plan, it is seen from the success of meeting and a meeting of the editor. ( 2 ) the organizing stages, the editor management has forming the organization structure and their duty to each personel.( 3 ) The mobilization phase is very important to editor management in daily newspaper of Radar Cirebon, because of mobilizarion, the management of material goes well, start from the reporting process, writing, editing till becoming the news. (4) In the phase supervision in editorial management of daily newspaper of Radar Cirebon conducted in the form of direct briefing to reporters during a news manuscript edited by the editor still experiencing a shortage of data.
\end{abstract}

Keyword: editorial management, daily newspaper

\begin{abstract}
Abstrak
Media massa setelah era reformasi menjadi sarana komunikasi massa dan alat pembentuk opini publik, sangatlah membantu dalam kehidupan manusia untuk saling bertukar pikiran, berbagi pengalaman, dan informasi dalam volume yang relatif besar. Penelitian ini bertujuan untuk mengetahui perencanaan, pengorganisasian, penggerakan serta pengawasan dalam manajemen redaksional pada Surat Kabar Harian Umum Radar Cirebon. Metode penelitian ini adalah deskriftip kualitatif, data dikumpulkan dengan menggunakan wawancara langsung, observasi dan studi kepustakaan. Dari hasil penelitan dapat ditarik kesimpulan bahwa (1) Pada tahap perencanaan, bidang redaksional Surat Kabar Harian Umum Radar Cirebon terencana dengan baik, hal ini terlihat dari terlaksananya rapat perencanaan liputan atau rapat redaksi. (2) Pada tahap pengorganisasian manajemen redaksional telah membentuk struktur organisasi dengan jabatan dan tugas masing-masing personil. (3) Tahap penggerakan merupakan tahap yang sangat penting dalam manajemen redaksional di Surat Kabar Harian Umum Radar Cirebon, karena dengan adanya penggerakan, proses pengelolaan materi pemberitaan berjalan dengan lancar, mulai dari proses peliputan, penulisan, sampai pada penyuntingan (editing) naskah berita. (4) Tahap pengawasan dalam manajemen redaksional pada Surat Kabar Harian Umum Radar Cirebon dilakukan dalam bentuk pengarahan langsung terhadap wartawan saat naskah beritanya diedit oleh redaktur masih mengalami kekurangan data.
\end{abstract}

Kata kunci : manajemen redaksional, surat kabar 


\section{Pendahuluan}

Media massa merupakan sarana manusia untuk memahami realitas. Oleh sebab itu media massa dituntut mempunyai kesesuaian dengan realitas dunia yang sebenarnya. Maksudnya gambar realitas yang ada di benak khalayak tidaklah bias karena informasi media tidak kontekstual dengan realitas. Era reformasi yang ditandai dengan maraknya media massa sebagai sarana komunikasi massa dan alat pembentuk opini publik, sangat membantu dalam kehidupan manusia untuk saling bertukar pikiran, berbagi pengalaman, dan informasi dalam volume yang relatif besar. Media massa membuka mata dan hati manusia untuk mengetahui berbagai peristiwa yang terjadi di belahan dunia, baik melalui media massa cetak maupun media massa elektronik.

Berbeda dengan media massa lainnya seperti televisi dan radio, media massa cetak merupakan media massa pertama yang dikenal manusia sebagai media yang memiliki ciri-ciri komunikasi massa, yaitu proses komunikasinya satu arah, komunikatornya melembaga dan heterogen, serta pesannya bersifat umum. Oleh karena itu kata pers yang melekat pada media massa cetak kemudian digeneralisasikan untuk menyebut media massa pada umumnya. Media massa cetak berbentuk surat kabar, tabloid, majalah, dan buletin, selain memiliki ciri-ciri komunikasi massa sebagai ciri umum, juga memiliki ciriciri khusus, yaitu: 1) Daya tampungnya tinggi, memiliki peluang untuk menambah halaman, 2) Daya dokumentasinya tinggi, mudah disimpan atau diperbanyak, dan 3) Jaringan distribusinya terbatas, karena sifatnya literer.

Memproduksi suatu penerbitan pers, masing-masing bidang (bidang redaksional, bidang cetak, dan bidang usaha) mempunyai tanggung jawab, peran serta tujuan yang sama. Oleh karena itu manajemen penerbitan pers harus mampu menciptakan, memelihara, dan menerapkan sistem kerja yang proporsional dalam menumbuh-kembangkan rasa kebersamaan di antara sesama personil di sebuah organisasi atau perusahaan.

Berkaitan dengan manajemen redaksional, Surat Kabar Harian Umum Radar Cirebon yang diterbitkan PT Wahana Semesta Cirebon (Group Jawa Pos), cukup lihai dalam mengolah materi pemberitaan yang sedemikian rupa, sehingga menjadi produk jurnalistik dalam bentuk berita yang menarik dan lebih mudah dipahami oleh khalayak pembaca. Keahlian tersebut tampak dalam kreatifitasnya menampilkan kejelasan gambar atau foto, membuat caption (keterangan gambar), menyajikan grafis, menampilkan headline yang menarik, memilih kosa kata, dan menyusun kalimat dalam beritanya dengan menggunakan bahasa yang sederhana. Uniknya, meskipun Surat Kabar Harian Umum Radar Cirebon tergolong pers lokal, namun kehadirannya disambut hangat oleh masyarakat Pantura, khususnya wilayah III Cirebon. Hal ini demi memenuhi kebutuhan akan informasi, pendidikan, berita, dan hiburan. Sehingga berbagai berita yang termuat dalam Surat Kabar Harian Umum Radar Cirebon tidak hanya meliputi peristiwa-peristiwa yang terjadi di Kota Cirebon saja, melainkan juga peristiwa-peristiwa yang terjadi di wilayah III Cirebon seperti, Kabupaten Cirebon, Kuningan, Majalengka dan Indramayu. Hal ini tentunya diperlukan manajemen redaksional yang dapat menjaga kualitas produk.

Surat Kabar Radar Cirebon juga harus mempertimbangkan beberapa aspek untuk menghasilkan produk yang berkualitas. Adapun pertimbangan yang digunakan bisa menyangkut aspek nilai berita, menarik tidaknya bagi pembaca, corak politik yang dianut penerbit pers tersebut, dan memperhatikan bahasa, akurasi, serta kebenaran tulisan beritanya agar tidak terjadi salah cetak.

Komunikasi massa merupakan proses komunikasi melalui media massa, jelasnya merupakan singkatan dari komunikasi media massa (mass media communication). Media yang digunakan dalam komunikasi massa ini meliputi surat kabar, majalah, radio, televisi, atau film. (Effendy, 2002: 20). Komunikasi massa menyiarkan informasi, gagasan dan sikap kepada komunikan yang beragam dalam jumlah yang banyak dengan menggunakan media. Adapun karakteristik komunikasi massa adalah ;

A. Komunikasi massa bersifat umum, bahwa pesan komunikasi yang disampaikan melalui media massa adalah terbuka untuk semua orang; 
B. Komunikan bersifat heterogen, bahwa massa dalam komunikasi massa terjadi dari orang-orang yang heterogen yang meliputi penduduk yang bertempat tinggal dalam kondisi yang berbeda, dengan kebudayaan yang beragam, berasal dari berbagai lapisan masyarakat, mempunyai pekerjaan yang berjenis-jenis, maka oleh karena itu mereka berbeda pula dalam kepentingan, standar hidup dan derajat kehormatan, kekuasaan, dan pengaruh;

C. Media massa menimbulkan keserempakan. Yaitu keserempakan kontak dengan sejumlah besar penduduk dalam jarak yang jauh dari komunikator, dan penduduk tersebut satu sama lainnya berada dalam keadaan terpisah;

D. Hubungan komunikan-komunikator bersifat non-pribadi karena komunikan yang anonim dicapai oleh orang-orang yang dikenal hanya dalam peranannya yang bersifat umum sebagai komunikator. (Effendy, 2000:79).

Meskipun setiap individu dalam masyarakat memiliki dunia persepsi dan pengalaman yang berbeda, namun kadang diperlukan persepsi yang sama terhadap suatu realitas tertentu sehingga membentuk kehidupan sosial yang baik. Di sinilah media massa berperan mengarahkan dan membentuk persepsi dan interpretasi masyarakat yang benar sehingga tercipta kehidupan sosial yang baik. Dalam proses komunikasi massa, peran media massa sangat penting. Media massa sebagai sebuah sarana atau media dimana pesan akan disalurkan dan disebarluaskan pada khalayak menurut Effendy, (2002:217). "Media massa (mass media) yaitu media komunikasi yang mampu menimbulkan keserempakan, dalam arti khalayak dalam jumlah yang relatif banyak secara bersamasama pada saat yang sama memperhatikan pesan yang dikomunikasikan melalui media tersebut, misalnya surat kabar, radio siaran, televisi siaran, dan sebagainya".
Ada lima jenis media masa yang dikenal sebagai "The big five of mass media" yaitu televisi, film, radio, majalah dan koran dengan fungsi komunikasi yang saling melengkapi yaitu Social Function bersifat sosiologis dan Individual Function dalam bukunya Effendy.

1. Social Function, yaitu fungsi komunikasi massa terhadap masyarakat, mencakup pengawasan lingkungan, korelasi antar bagian di dalam masyarakat untuk menanggapi lingkungannya, sosialisasi atau pewarisan nilai-nilai dan hiburan.

2. Individual Function, yaitu fungsi komunikasi massa terhadap individu, mencakup pengawasan atau pencarian informasi, mengembangkan konsep diri, memfasilitasi dalam hubungan sosial, substitusi dalam hubungan sosial, membantu melegakan emosi, sarana pelarian dari ketegangan dan keterasingan, dan bagian dari kehidupan rutin atau ritualisasi.

Dampak pesan pada media massa meliputi dampak kognitif, afektif, dan konatif. Dampak pesan media massa yang berupa pola-pola tindakan, kegiatan atau perilaku yang dapat diamati, adalah dampak pesan media massa yang telah sampai pada tahap konatif. Secara teoritis dampak pesan media massa biasanya hanya sampai pada tahap kognitif dan afektif, tetapi ada beberapa kondisi yang menyebabkan dampak pesan media massa sampai pada tahap konatif yaitu: a) Exposure (jangkauan pengenaan), jika sebagian besar khalayak telah terekspos oleh media massa; b) Kredibilitas, jika pesan media massa mempunyai kredibilitas yang tinggi di mata khalayaknya dalam arti kebenarannya dapat dipercaya; c) Konsonasi, jika isi informasi yang disampaikan oleh beberapa media massa baik materi, arah serta orientasinya maupun dalam hal waktu, frekuensi dan cara penyajiannya sama atau serupa; d) Signifikansi, jika materi pesan media masa signifikan dalam arti berkaitan secara langsung dengan kepentingan dan kebutuhan khalayak; e) Sensitif, jika materi dan penyajian pesan media massa menyentuh hal-hal yang sensitive; f) Situasi kritis, jika ada ketidakstabilan struktural yang 
menyebabkan masyarakat berada dalam situasi kritis; g) Dukungan komunikasi antar pribadi, jika informasi melalui media massa menjadi topik pembicaraan, karena didukung oleh komunikasi antar pribadi. (Effendy, 2002:31).

Media senantiasa menjadi pusat perhatian dalam membahas komunikasi massa manapun. Melalui media, pesan-pesan dapat disebarluaskan ke berbagai penjuru, dapat mempengaruhi, sekaligus mencerminkan budaya masyarakat dimana media tersebut hadir. Cara pandang media dalam menyajikan realitas sangat dipengaruhi oleh sistem politik yang berlaku pada masanya. Hal ini dapat terlihat dari hasil liputan media dalam mengangkat suatu realitas sosial. Kata media tentu saja menyiratkan arti mediasi atau sebagai perantara karena keberadaanya di antara audiens dan dunia sekitarnya (lingkungan). Denis Mc Quail dalam bukunya Teori Komunikasi Massa (1996: 27) misalnya menyebutkan beberapa perumpamaan untuk menjelaskan gagasan tersebut: "Media, misalnya merupakan jendela yang memungkinkan kita dapat melihat apa yang ada diluar lingkungan langsung kita, sebagai penterjemah yang dapat membantu kita memahami pengalaman baik langsung maupun secara simbolik, sebagai landasan atau pembawa informasi bagi para audiens dalam menentukan sikap, sebagai ramburambu yang yang memberikan instruksi dan arahan, penyaring bagian-bagian dari pengalaman, sekaligus menitikberatkan pada bagian yang lain, sebagai cermin yang memantulkan bayangan kita kembali pada kita sendiri dan sebagai penghalang yang merintangi kebenaran itu sendiri".

Media Massa (Mass media) yaitu media komunikasi yang mampu menimbulkan keserempakan, dalam arti khalayak dalam jumlah yang relatif banyak secara bersama-sama pada saat yang sama m e m perhatikan pesan yang dikomunikasikan melalui media tersebut, misalnya surat kabar, radio siaran, televisi siaran, dan sebagainya (Effendy, 2002:217). Adapun fungsi media massa adalah: a) Menyiarkan informasi, sebab masyarakat membeli media massa memerlukan informasi tentang berbagai hal yang terjadi di dunia ini; b) Mendidik, artinya media massa menyajikan pesan-pesan atau tulisan-tulisan yang mengandung pengetahuan, serta sekaligus dijadikan media pendidikan massa; c) Menghibur, biasanya media massa menyajikan rubrik-rubrik atau programprogram yang bersifat hiburan; $d$ ) Mempengaruhi, melalui fungsi ini media massa memegang peranan penting dalam tatanan kehidupan masyarakat.

Salah satu media massa yang berkemampuan memikat perhatian khalayak secara serentak (simultaneous) dan serentak (instantaneous) adalah pers. Pers merupakan media yang paling sering menimbulkan masalah dalam semua bidang kehidupan dan semakin lama semakin canggih akibat perkembangan teknologi, sehingga senantiasa memerlukan pengkajian yang seksama. Pers memiliki ciri khas dibandingkan media massa lainnya. Bukan hanya sifatnya yang merupakan media cetak, tetapi khalayak yang diterpanya bersifat aktif, tidak pasif seperti kalau mereka diterpa media radio, televisi, dan film. Pesan melalui media pers diungkap dengan huruf-huruf mati, yang baru menimbulkan makna apabila khalayak menggunakan tatanan mentalnya (mental set) secara aktif. Kelebihan pers lainnya ialah bahwa media cetak dapat didokumentasikan, dikaji ulang, dihimpun untuk kepentingan pengetahuan, dan dijadikan bukti otentik yang bernilai tinggi.

Dampak komunikasi massa dalam tulisan ini akan dilihat dari dua aspek yaitu dampak yang berkaitan dengan media secara fisik dan dampak yang berkaitan dengan pesan media massa. Adapun dampak media massa sebagai obyek fisik diantaranya: a) Dampak Ekonomis, dimana kehadiran media massa dapat menggerakkan usaha dalam berbagai sektor seperti produksi, distribusi dan konsumsi jasa media massa; b) Dampak Sosial, dimana status pemilik (memiliki televisi atau radio, berlangganan surat kabar atau majalah) secara tidak langsung meningkat dengan kepemilikan media massa; c) Dampak pada penjadwalan kegiatan, dimana kegiatan sehari-hari khalayak dapat berubah dengan hadirnya media massa, misalnya jadwal tidur seseorang ,menjadi larut, karena ia selalu menonton tayangan televisi "Buletin Malam"; 
d) Sebagai penyaluran perasaan tertentu, dimana tanpa mempersoalkan pesan yang disampaikan media massa orang menonton televisi atau memutar gelombang radio hanya untuk menghilangkan rasa kecewa, sedih, bosan atau perasaan lain (Effendy, 2002:137). Dukungan komunikasi antar pribadi, jika informasi melaui media massa menjadi topik pembicaraan, karena didukung oleh komunikasi antar pribadi.

Jurnalisme merupakan keseluruhan proses dari pengumpulan, penulisan, penyuntingan, dan penyiaran berita (Effendy, 2000: 95). Sedang kegiatan jurnalistik merupakan keseluruhan proses mulai dari mencari, memperoleh, memiliki, menyimpan, mengolah, dan menyampaikan informasi berupa berita atau pendapat kepada khalayak pembaca. Menurut Undang-Undang No.40 tahun 1999 tentang pers: "Bahwa kegiatan jurnalistik meliputi mencari, memperoleh, memiliki, menyimpan, mengolah, dan menyampaikan informasi baik dalam bentuk tulisan, tulisan, suara, gambar, suara dan gambar, serta data dan grafik maupun dalam bentuk lainnya dengan menggunakan media cetak, media elektronik, dan segala jenis saluran yang tersedia". Dasarnya inti dari jurnalistik adalah adanya suatu fakta yang direkonstruksi kembali oleh wartawan atau lembaga media yang disampaikan pada masyarakat luas. Merekonstruksi suatu fakta, wartawan maupun media juga harus menginterpretasikan fakta atau realitas sosial yang diperolehnya dengan benar dan sejelas mungkin. Selanjutnya, masyarakatlah yang berhak menginterpretasikan berita dan memberikan konteks tertentu atas informasi yang diterimanya.

Wartawan maupun media massa harus mampu merangsang masyarakat untuk menginterpretasikan berita yang ada di surat kabar dan memberinya konteks. Hal itu bisa terjadi bila berita yang disajikan oleh media massa memiliki nilai sosial dan menguntungkan bagi kepentingan umum. Suatu nilai sosial dapat terpenuhi apabila media mampu mengakomodasikan kepentingan masyarakat dengan berita dan informasi yang disampaikannya.

Penelitian ini mencoba untuk melihat dan mendeskripsikan manajemen redaksional yang dilakukan Surat Kabar Harian Umum Radar Cirebon periode Januari-Mei 2013 sebagai media massa cetak yang mampu memberikan atau menyajikan informasi dalam bentuk berita yang menjadi kebutuhan khalayak pembaca.

\section{Metode Penelitian}

Penelitian ini mengacu pada penelitian jenis kualitatif, yaitu prosedur penelitian yang menghasilkan data deskriptif berupa kata-kata tertulis atau lisan dari individu atau kelompok yang perilakunya diamati. Sedangkan ditinjau dari sifatnya, penelitian ini termasuk penelitian deskriptif, yaitu penelitian yang bertujuan menggambarkan secara sistematis dan akurat, fakta dan karakteristik mengenai populasi atau bidang tertentu. Adapun pihak yang dijadikan Informan dan sumber data dalam penelitian ini adalah:

a. Data primer, yaitu data yang diperoleh langsung dari narasumber. Dalam hal ini adalah Pemimpin Umum, Pemimpin Redaksi, dan staf bidang redaksional.

b. Data sekunder, yaitu data yang diperoleh dari catatan atau dokumen Harian Radar Cirebon. Sedangkan fokus penelitian adalah pada manajemen redaksional Surat Kabar Harian Radar.

\section{Hasil Penelitian dan Pembahasan}

Memproses sebuah isu menjadi berita yang menarik. Ada beberapa elemen yang harus diperhatikan, salah satu di antaranya yaitu fungsi manajemen (function of management) yang dijalankan oleh media itu sendiri, baik cetak maupun elektronik (Totok Djuroto, 2006: 96). Sebuah media cetak mencari berita, menuliskan, mengedit naskah, hingga menyebarkan informasi. Pencari berita pada media catak dituntut bagaimana ia dapat mencari dan menuliskan berita dalam waktu yang relatif singkat dengan gaya bahasa berita langsung (straight news), tidak bertele-tele, singkat, dan jelas dengan data tentatif yang didapat dari lapangan.

Hal tersebut dilakukan karena saat ini sebagian orang membutuhkan informasi yang cepat dan akurat. Jika fungsi manajemen tidak dijalankan dengan baik, tentulah akan terjadi 
penumpukan kewajiban pada setiap bagian. Jika terjadi demikian, maka akan mengakibatkan lambannya informasi yang didapat oleh khalayak. Pada dasarnya, fungsi manajemen pada media catak yang dijalankan dengan sistematis dan terarah, akan menghasilkan produk (berita) yang baik, siap untuk menjadi suatu berita yang menarik pada Surat kabar harian Radar Cirebon.

Berita-berita itu didapat dari dua sumber yaitu kantor berita dan reportase para wartawan di lapangan. Manajemen keredaksian mencakup perencanaan, pengorganisasian, pengarahan, dan pengawasan terhadap pengadaan, pengembangan, kompensasi, integrasi dan pemeliharaan orang-orang dengan tujuan membantu mencapai tujuan organisasi (pers), individual, dan masyarakat. (Stefanus Akim, http:/ / stefanusakim.multiply.com/journal/ item/19/ manajemen keredaksian, di akses pada 19 April 2013 21:32:36) Terkait dengan definisi di atas, berikut akan dijelaskan lebih dalam lagi bagaimana penerapan delapan fungsi manajemen keredaksian yang dijalankan oleh Harian Umum Radar Cirebon, baik dari fungsi perencanaan hingga berita siap diterbitkan.

\section{Perencanaan}

Harian Umum Radar Cirebon merupakan organisasi media cetak yang telah mengandalkan teknologi baik dalam hubungan antar staf redaksi maupun dalam memproses berita hingga berita siap terbit. Perkembangan terus dilakukan oleh media ini, sehingga Surat Kabar Harian Umum Radar Cirebon dapat benar-benar menjalankan fungsi manajemen media dengan sistematis dan terarah, terlebih kepada fungsi perencanaan. Sebagai media cetak, Surat Kabar Harian Umum Radar Cirebon tentu menjalani fungsi perencanaan. Menekankan harus bertatap muka setiap harinya. Media ini lebih mengandalkan teknologi untuk berinteraksi antar redaksi. Rapat diadakan setiap hari, pada pagi dan sore hari. Rapat itulah yang wajib dihadiri oleh seluruh reporter.

Tahap perencanaan dalam manajemen redaksional untuk surat kabar harian adalah penentuan kebijakan isi pemberitaan untuk esok pagi, dan membahas berita-berita yang perlu ditindaklanjuti. Berita yang baik adalah hasil perencanaan yang baik.
Prinsip ini berlaku bagi berita yang sifatnya diduga. Proses pencarian dan penciptaan berita dimulai di ruang redaksi melalui forum rapat proyeksi atau rapat perencanaan berita. Rapat biasanya diselenggarakan pagi dan sore atau malam hari, yang dihadiri beberapa redaktur dan pemimpin redaksi. Rapat proyeksi diusahakan singkat, tidak lebih dari 60 menit dan diselenggarakan secara rutin, setiap reporter atau wartawan mengajukan usulan liputan. Perencanaan akan dibahas mengenai pembagian tugas peliputan dan jumlah yang diutus untuk meliput berita tersebut.

Fungsi perencanaan, sebagaimana telah diurai pada bagian sebelumnya, merupakan kegiatan yang dimulai dari pembahasan ide (gagasan) awal sampai dengan pelaksanaan proses pencarian berita. Begitu pun pada Harian Umum Radar Cirebon, menurut Redaktur pelaksana Rusdi, "Fungsi perencanaan menempati bagian terpenting dalam proses penyajian berita, karena menentukan berita yang akan di sajikan esok hari. Pembagian tugas menurut desk masingmasing rubrik dibagi dalam proses perencanaan di proyeksi harian yang di terapkan Surat Kabar Harian Umum Radar Cirebon". Fungsi perencanaan, disebutkan bahwa dalam rapat redaksi rutinan, terjadi proses interaksi dan kreativitas para staf redaksi. Baik buruknya proses produksi berita juga sangat ditentukan oleh perencanaan yang dikonsep di atas kertas (outline) berupa pembagian tugas pencarian berita hingga berita siap terbit.

Proses perencanaan ada beberapa langkah yang harus dilalui. Sebagaimana yang telah diurai, proses perencanaan dan penetapan mencakup beberapa langkah, berikut ialah pengaplikasiannya pada Harian Umum Radar Crebon:

1. Menetapkan peran dan misi. Dalam masalah visi dan misi, Harian Umum Radar Cirebon mengedepankan misi sebagai Koran diwilayah III Cirebon yang membutuhkan sebuah Koran harian yang terpercaya, yang mampu menjawab tantangan era globalisasi bersamaan dengan visinya yang probisnis. 
1. Menentukan wilayah sasaran. Wilayah sasaran Harian Umum Radar Cirebon, ditujukan untuk masyarakat Pantura dan Wilayah III Cirebon.

2. Tim Redaksi Harian Umum Radar Cirebon juga mengidenktifikasi dan menentukan indikator efektivitas (indicators of effectiveness) dari setiap pekerjaan yang telah, sedang, dan akan dilaksanakan.

3. Menentukan hasil yang ingin dicapai Harian Umum Radar Cirebon berupa rencana yang harus dicapai dalam jangka panjang dengan selalu berinovasi.

4. Tim Redaksi Harian Umum Radar Cirebon juga mempersiapkan rencana tindakan yang terdiri dari langkahlangkah sebagai berikut:

(a)Menentukan urutan tindakan yang akan dilakukan untuk mencapai tujuan. Tindakan ini lebih ditegaskan saat rapat redaksi. (b)Penjadwalan (scheduling) menentukan waktu yang diperlukan untuk mencapai tujuan atau sasaran. Harian Umum Radar Cirebon menentukan penjadwalan dan penugasan untuk para reporter yang tergabung ke dalam newsroom agar mereka melaksanakan tugas peliputannya. (c)Anggaran (budgeting) menentukan sumber-sumber yang dibutuhkan untuk mencapai tujuan. Harian Umum Radar Cirebon juga memperhitungkan dengan cermat masalah iklan masuk dan biaya- biaya lainnya seperti penugasan pemimpin redaksi maupun reporter untuk mengikuti perkembangan yang terjadi.(d) Pertanggungjawaban, menetapkan siapa yang akan mengawasi pemenuhan tujuan yaitu pihak yang menyatakan tujuan sudah tercapai atau belum.(e)Menguji dan merevisi rencana sementara (tentative plan). Tidak ada penerapannya pada Harian Umum Radar Cirebon.(f ) Membangun pengawasan, yaitu memastikan tujuan akan terpenuhi. Pengawasan secara detail hanya dilakukan oleh Kepala Bagian Marketing dan Pemimpin Redaksi Harian Umum Radar Cirebon. Kepala Bagian Marketing fokus pada masalah iklan, sedangkan redaksi fokus pada masalah pemberitaan.(g) Komunikasi-komunikasi organisasi yang digunakan oleh Iing Casdirin sebagai pemimpin redaksi, terhadap para bawahannya tergolong cukup baik, sehingga para stafnya melakukan tugasnya dengan hati yang ikhlas dan senang. (h)Pelaksanaan, Tim Redaksi Harian Umum Radar Cirebon juga membuat persetujuan mengenai komitmen untuk menjalankan apa yang telah ditentukan. Upaya ini dilakukan namun tidak dalam betuk tertulis. Seperti diungkapkan Redaktur Pelaksana Rusdi menjelaskan:

"Fungsi perencanaannya tim redaksi harus berkumpul jam 08.00 WIB setiap harinya untuk merencanakan pembagian tugas dan berita apa saja yang harus mereka liput, para tim redaksi pun menggunakan alat komunikasi (handphone) untuk berkoordinasi. Setelah itu jam 16.00 WIB memberikan pelaporan peliputan dalam meja rapat redaksi dan menulisnya setelah pelaporan selesai. Para staf redaksi Harian Umum Radar Cirebon tetap mengadakan rapat redaksi formil. Rapat itu biasanya dilakukan sebulan dua kali dan wajib dihadiri oleh seluruh reporter yang bertugas dan membahas mengenai bagaimana isi berita Harian Umum Radar Cirebon ke depannya dan evaluasi kinerja para reporter."

Pertemuan tatap muka akan merencanakan berita apa saja yang akan mereka liput. Iing Casdirin, selaku Pemimpin Redaksi Harian Umum Radar Cirebon bertugas mengarahkan dan memberikan tugas peliputan sesuai dengan job masingmasing dengan tetap memantau kinerja para reporternya. Adapun peristiwa-peristiwa yang tidak terduga yang sifatnya aktual wartawan harus cepat mendapatkan informasi tentang kejadian tersebut dengan segera meliputnya. Seusai rapat redaksi selesai, biasanya para reporter segera menuju lokasi masing-masing dan harus kembali lagi ke kantor redaksi. Setelah berhasil meliput berita yang didapat di lapangan.

Pada rapat redaksi sore membahas angle mana yang akan sajikan ke depannya. Rapat itu juga wajib dihadiri oleh semua reporter yang bertugas. Dalam rapat sore wartawan melaporkan data yang telah diliput pada redakturnya dan membahas yang menarik yang akan diangkat dalam pengolahan berita. 
Dari uraian tersebut, dapat disimpulkan bahwa, fungsi perencanaan yang diterapkan pada Harian Umum Radar Cirebon dapat dikatakan baik dan maksimal. Baik, karena pertama perencanaan itu tetap ada. Kedua, perencanaan yang disusun pada akhirnya akan dijalani oleh setiap reporter yang bertugas di lapangan untuk meliput berita, terbukti dengan mampunya tim redaksi untuk memproduksi sekitar 200-250 berita perharinya. Ketiga, perencanaan yang diterapkan oleh pemimpin redaksi, namun pemimpin redaksi cukup memerintahkan berita mana yang harus reporter liput. Sedangkan maksimalnya karena ada jadwal tertulis perihal rapat rutin. karena bertemu tatap muka akan lebih terlihat ketegasan dan kesigapan reporter dibandingkan dengan memerintah hanya menggunakan alat komunikasi semata.

\section{Pengorganisasian}

Tahap pengorganisasian dalam manajemen redaksional adalah penyusunan struktur organisasi dan pembagian tugas pekerjaan serta penempatan orang berikut jabatannya di dalam struktur organisasi. Pada proses redaksional terdapat staffing yang berfungsi untuk melaksanakan aktifitas redaksional (Djuroto, 2006: 117). Fungsi pengorganisasian yang diterapkan dalam Harian Umum Radar Cirebon masih dijalankan secara normatif seperti media massa pada umumnya. Menurut Pemimpin Redaksi ling Casdirin:

"Perbedaan signifikannya terletak pada panduan untuk memonitor kinerja para staf redaksi, berupa tingkat kedisiplinan yang tinggi. Hal dapat mempengaruhi fungsi pengorganisasian dalam yang dijalani pemimpin redaksi Surat Kabar Harian Umum Radar Cirebon kepada para bawahan. Kita menggunakan Corporate Performance Management (CPM). Corporate Performance management (CPM) adalah usaha untuk mendapat hasil yang lebih baik, baik bagi organisasi, tim maupun individual dengan memahami dan memanaj performance dalam kerangka tujuan, standar dan kompetensi yang terencana dan telah disepakati bersama. CPM ini adalah standar untuk memonitor fungsi organisasi. Intinya adalah untuk memonitor. Misalnya, marketing itu dianggap bagus sekali jika bisa mendapatkan revenue 15 Milyar per tahun."

Wartawan yang telah diberikan tugas dimonitor melalui proses perencanaan dan diukur dari apa yang telah mereka laksanakan. Ini dilakukan dengan membawa data yang akan diolah sesuai dengan proyeksi. Wartawan dituntut untuk bertanggung jawab penuh dalam melaksanakan tugas yang diberikan. Tujuan dari perencanaan dalam redaksional bisa tercapai sesuai dengan yang diinginkan.

Namun pada bagian pemberitaan, redaktur mempunyai indikator sendiri, misalnya kecepatan pengiriman berita, kekuatan narasumber, dan bagus buruknya teks berita. Seperti yang telah diurai pada bagian sebelumnya, media penyiaran komersil, baik cetak, elektronik maupun online memiliki beberapa departemen atau bagian, yaitu sebagai berikut: a) Departemen Pemasaran. Departemen ini fokus dalam menangani kegitan yang terkait dengan pemasaran dan mempromosikan program maupun segala kegiatan kepada beberapa pihak atau partner kerja. Dalam Surat Kabar Harian Umum Radar Cirebon, departemen pemasaran dikepalai oleh Syahbana yang bertanggung jawab penuh terhadap iklan yang hendak masuk; 2) Departemen Program. Departemen ini tidak ada karena departemen ini sama seperti departemen berita yang sepaket dengan rubrik yang hadir di Surat Kabar Harian Umum Radar Cirebon; 3) Departemen Berita. Departemen ini dipimpin oleh seorang pemimpin redaksi. Departemen berita bertanggung jawab terhadap produksi program berita, olahraga, dokumenter dan program-program yang terkait dengan kepentingan khalayak. Harian Umum Radar Cirebon, departemen berita langsung ditangani oleh redaktur dengan persetujuan pemimpin redaksi untuk kemudian dipilih mana yang layak terbit; 4) Departemen Teknik. Departemen ini bertanggung jawab penuh terhadap segala hal yang terkait dengan peralatan siaran agar program atau berita dapat disiarkan. Jika dalam media TV para staf teknik mengoperasikan peralatan di control room, maka dalam Harian Umum Radar Cirebon layouter fokus mengurusi tampilan (layout) tersebut. 
Fungsi pengorganisasian, mungkin akan berbeda antara satu perusahaan media satu dengan media lainnya. Namun tujuannya satu, agar kinerja para staf redaksi dapat termonitor dengan baik. Berkumpul untuk bertatap muka mengedepnkan kedisiplinan terus ditingkatkan secara maksimal. Dalam kesehariannya, Harian Umum Radar Cirebon memakai sistem Corporate Performance Management (CPM) sebagai pedoman untuk memonitor kinerja para staf redaksi Harian Umum Radar Cirebon. Di dalam CPM itulah terdapat peraturan yang harus dilaksanakan oleh para pimpinan, karyawan dari tingkat atas hingga bawah. Fungsi utama CPM ialah untuk memonitor semua fungsi organisasi dalam Harian Umum Radar Cirebon. Selain untuk memonitor, redaktur Harian Umum Radar Cirebon dengan mengacu kepada CPM mempunyai indikator (penilaian) untuk para reporter itu sendiri. Sedangkan untuk redaktur, Kepala Redaksi atau Bagian Operasional, terdapat beberapa orang (tim) lagi di atasnya untuk menilai kinerja mereka, begitu seterusnya.

Sebagai media cetak, Surat Kabar Harian Umum Radar Cirebon mempunyai dua fungsi besar yaitu fungsi melayani dan fungsi bisnis. Fungsi melayani berarti Harian Umum Radar Cirebon wajib memberikan pelayanan yang baik yang dalam hal ini memberitakan sesuatu dengan berimbang dan sesuai fakta. Sedangkan fungsi bisnisnya, Harian Umum Radar Cirebon juga tetap menerima iklan yang masuk ke dalam Koran mereka tanpa harus berat sebelah dan netral (imparsialitas). Artinya, selama iklan itu baik dan menguntungkan, maka Surat Kabar Harian Umum Radar Cirebon akan meresponnya dan menerima dengan baik.

Kebijakan ini diambil agar tidak hanya pendapatan yang diperoleh, namun juga sesuai dengan ideologi, visi, maupun misi media cetak yang probisnis. Selain itu, iklan yang hendak masuk terlebih dahulu dikoordinasikan dengan pihak pusat Harian Umum Radar Cirebon agar dapat ditentukan layak terima atau tidak. Dalam fungsi pengorganisasian, output yang dihasilkan ialah suatu struktur organisasi agar pembagian tugas lebih fokus. Oleh karenanya, di bawah ini akan dideskripsikan bagaimana struktur organisasi pada Harian Umum Radar Cirebon. Harian Umum Radar Cirebon dikepalai oleh seorang pemimpin redaksi.
Pempinan redaksi saat ini adalah ling Casdirin. Pemimpin redaksi bertanggung jawab untuk memantau seluruh kinerja para stafnya juga bersedia membantu segala kesulitan yang mungkin ditemui oleh setiap karyawannya. Di bawah Pemimpin redaksi Harian Umum Radar Cirebon ada Kepala Bagian Redaksi.

Kepala Bagian Operasional dipimpin oleh Rusdi, bertanggung jawab penuh terhadap segala hal yang berkaitan dengan pemberitaan. Dengan kata lain, Rusdi berkewajiban melakukan riset terhadap tulisan mana yang layak. Selanjutnya, Kepala Bagian Redaksi Surat Kabar Harian Umum Radar Cirebon yang bertanggung jawab penuh terhadap semua hal yang berkaitan dengan isi berita. Arif juga berkewajiban untuk mengingatkan para stafnya agar tidak lamban dalam bekerja, hal ini penting agar berita-berita pada Surat Kabar Harian Umum Radar Cirebon bisa berimbang.

Rusdi membawahi semua reporter yang bertugas. Reporter inilah yang terkumpul ke dalam news room Surat Kabar Harian Umum Radar Cirebon untuk mencari dan menghimpun berita lalu menuliskan untuk kemudian dikirim ke redaktur. Selanjutnya, ada beberapa orang yang bertanggung jawab atas tampilan (layout) Harian Surat Kabar Umum Radar Cirebon. Tim layout bertugas mendesain Surat Kabar Harian Umum Radar Cirebon agar enak dilihat serta nyaman dibaca bagi seluruh pembca.

Sebagai media cetak, Surat Kabar Harian Umum Radar Cirebon juga melaksanakan fungsi bisnis untuk mendapatkan pendapatan yang meningkat. Pemilihan iklan yang masuk tersebut bukan hanya berdasar karena royalti yang didapat. Namun, seluruhnya telah memenuhi syarat dan sesuai dengan visi misi Harian Umum Radar Cirebon. Kesemuanya telah dipilih dengan pertimbangan total dan maksimal. Pemilihan iklan partai pun bukan karena Surat Kabar Harian Umum Radar Cirebon berpihak pada partai tersebut, namun iklan-iklan itulah yang dirasa memenuhi persyaratan dan tidak keluar dari jalur visi dan misi Surat Kabar Harian Umum Radar Cirebon. Selain iklan di atas, Surat Kabar Harian Umum Radar Cirebon juga menjalin kerja sama dengan jenis iklan lain, misalnya iklan makanan, minuman, bank, dan lain sebagainya. Namun sebaliknya, jika pengiklan itu hendak masuk namun tidak sesuai dengan persyaratan yang 
diajukan Surat Kabar Harian Umum Radar Cirebon dan tidak sesuai dengan visi misi Surat Kabar Harian Umum Radar Cirebon, maka akan ditolak dengan cara sewajarnya, meskipun income yang didapat begitu besar. Itulah, dalam hal ini tingkat keidealisan suatu media dipertaruhkan.

Dengan kata lain, Surat Kabar Harian Umum Radar Cirebon bukan hanya ingin meraup keuntungan sebanyak mungkin, namun juga bagaimana keuntungan itu diperoleh dengan cara yang baik. Penilaian kinerja wartawan bisa dilihat dan dinilai. Nilainya itu setiap tulisan dan tiap bulan diakumulasi, belum lagi performance secara umum. Misalnya, wartawan ini tidak pernah masuk ke kantor, tidak pernah ikut rapat, hingga pernah datang rapat koordinasi. Menurut Rusdi, ketidakjujuran para reporter akan dapat diketahui dengan kedisiplinan mereka mengirim berita. Jadi, jika ada reporter yang mengaku dirinya sibuk dan tidak dapat meliput, akan dapat diketahui dari data intensitas mereka mengirim berita kepada para redakturnya dalam sebulan. Kedisiplinan inilah yang akan dinilai. Menurut Rusdi, masalah produktivitas memang tak dapat dibohongi.

Hal itu pulalah yang menyebabkan kenaikan kompensasi dapat diraih jika karyawan berusaha untuk memenuhi indikator. Misalnya dalam pengiriman berita, semua itu ada indikatornya, berupa kecepatan, kekuatan narasumber dan redaksi teks. Seperti yang telah diurai sebelumnya, setelah kinerja staf redaksi termonitor melalui $\mathrm{CPM}$, maka pimpinan mereka menggunakan CPM untuk memonitornya. Sehingga tingkat kedisiplinan menghadiri rapat, mengirim berita, performa keseharian di kantor redaksi, redaksi berita yang dikirim kepada redaktur mereka masing-masing dan lain sebagainya menjadi pertimbangan yang sangat mempengaruhi kenaikan kompensasi maupun jabatan untuk para staf Surat Kabar Harian Umum Radar Cirebon. Indikator tiaptiap desk berbeda.

Bagian redaksi berkaitan dengan pengiriman berita, maka dalam bagian operasional, misalnya, bagian ini berkaitan dengan pendapatan pertahun. Dari uraian di atas, maka berikut ini akan dipaparkan mengenai deskripsi penilaian dari redaktur untuk para reporter beserta indikatornya: 1) Intensitas mengirim berita, 2) Kerapihan, 3) Kehadiran rapat bulanan, dan 4) Redaksi teks berita.
Keempat faktor di atas selanjutnya akan dikalkulasikan untuk kemudian ditetapkan berapa kompensasi bulanan yang patut diperoleh. Karena panduan CPM inilah tindak nepotisme sulit terjadi. Nepotisme yang dimaksud di sini ialah jika ada seorang staf yang diterima karena ia memiliki sanak saudara atau pun sebagainya, kompensasi mereka akan kecil jika kinerja mereka kurang baik. Begitupun sebaliknya, kompensasi mereka pun akan besar jika kinerja mereka bagus dengan kedisiplinan yang tinggi. Kompensasi tersebut diperoleh dengan berbeda-beda tiap bulannya karena kembali kepada kinerja perbulan mereka. Jika kita kembali kepada teori, menurut Totok Djuroto dalam bukunya Manajemen Penerbitan Pers, struktur organisasi sebuah media itu terbagi atas dua bagian besar yaitu bagian bisnis dan redaksi.

Bagian bisnis ialah tugas seorang kepala bagian marketing, sedangkan bagian redaksi bertugas untuk memproduksi berita. Setelah kepala bagian redaksi, di bawah mereka ada redaktur yang bertugas mengedit berita dan para reporter yang bertugas. Dari uraian panjang lebar di atas dapat disimpulkan bahwa fungsi pengorganisasian Harian Umum Radar Cirebon sudah tergolong dengan baik, sebab telah Harian Umum Radar Cirebon telah berpedoman pada Corporate Performance Management. Selain itu, fungsi pengorganisasian juga telah termonitor yang menyebabkan kinerja reporter selalu terpantau dan kemudian akan dinilai.

\section{Penggerakan}

Tahap penggerakan dalam manajemen redaksional adalah aktivitas yang menggerakkan orang-orang beserta fasilitas penunjangnya untuk mencapai tujuan yang telah ditentukan, yaitu menghasilkan produk jurnalistik. Aktivitas tersebut meliputi peliputan, penulisan, dan penyunting berita. Penggerakan berarti fungsi yang dijalankan pada media massa berupa pengarahan seorang pemimpin agar para stafnya bersedia melaksanakan tugas, mendorong dan memotivasi bawahan, serta menciptakan iklim atau suasana pekerjaan yang kondusif, khususnya dalam metode komunikasi dari atas ke bawah atau sebaliknya, sehingga timbul saling pengertian yang baik serta 
menumbuhkembangkan disiplin kerja dan rasa saling memiliki. Begitu pula dengan tim redaksi Surat Kabar Harian Umum Radar Cirebon.Fungsi penggerakan menjadi penting bagi sebuah media massa karena setiap media idealnya mempunyai ideologi maupun visi misi masing-masing. Jika fungsi penggerakan dapat diterapkan secara terarah, maka para staf redaksi akan mengerti betul akan tujuan media yang mereka naungi termasuk menyusun redaksi berita yang mereka liput.

Proses peliputan dalam manajemen redaksional adalah mencari berita (news hunting), atau meliput bahan berita. Aktivitas meliput berita dilakukan setelah melewati proses perencanaan dalam rapat proyeksiredaksi. Dalam meliput berita terdapat tiga teknik, yaitu reportase, wawancara, dan riset kepustakaan (studi literatur).

Seorang reporter atau wartawan Surat Kabar Harian Umum Radar Cirebon akan mencari suatu data untuk didajikan berita dengan mengacu pada proyeksi yang sudah di berikan pada rapat redaksi pagi. Jika akan mengangkat isu yang sedang hangat terjadi sorang wartwan mencari data dengan reportase pada pihak yang terkait, bisa juga mengambil dari literature yang sudah ada. Adapun seorang wartawan menemui suatu peristiwa yang terjadi dari info ataupun proyeksi redaktur, seorang reporter/wartawan mencari data wawancara dengan pihak yang terlibat dalam kejadian atau peristiwa yang terjadi.

Pengolahan data seperti berita isu membutuhkan ketepatan dengan nara sumber yang terkait, jika tidak akurat bias menjadi kendala dalam proses peliputan. Ini menjadi hambatan yang sering terjadi di lapangan. Menurut wartawan Surat Kabar Harian Radar Cirebon Ida Ayu Komang yang bertugas di bagian Kota Cirebon dalam desk kedinasan dan kebijakan pemerintah menuturkan:

"Hal yang paling menjadi kendala dalam peliputan adalah menemui nara sumber yang terkait dengan isu yang sedang di bahas, seperti kebijakan, orang yang di jadikan narasumber seperti kepala dinas biasanya susah untuk di temui dan jika di temui enggan memberikan komentar terhadap isu yang terkait. Maka proses pendekatan perlu kepada narasumber untuk mendapatkan data, jika susah di temui menghubungi lewat telepon menjadi cara terakhir untuk mengkonfirmasi isu yang berkembang."

Proses peliputan seperti isu membutuhkan suatu teknik pendekatan terhadap nara sumber yang terkait untuk bias mendapatkan data. Kemampuan seorang wartawan dituntut bisa melakukan hal pandai melakukan pendekatan agar narasumber bisa memberikan keterangan untuk isu yang sedang di angkat. Dalam peliputan peristiwa yang tidak terduga bisa melakukan pendekatan pihak terkait dengan peristiwa seperti saksi jika meliput suatu kejadian misalnya kebakaran.

Peliputan suatu peristiwa yang tidak terduga menjadi proses yang harus segera di lakukan dindakan mencari data terkait. Misalnya suatu peristiwa kebakaran yang terjadi, seorang wartawan harus sigap dalam melakukan tindakan jika ada info terjadi kejadian kebakaran. Info yang di dapat harus segera di cek seperti mendatangi tempat kejadian. Jika benar terjadi hal yang pertama adalah mengambil gambar tempat kejadian.

Aktivitas peliputan, akhir-akhir ini banyak media massa cetak yang tidak hanya menugaskan wartawan atau reporter saja untuk meliput berita, akan tetapi wartawan foto atau fotografer juga diikutsertakan di Surat Kabar Harian Umum radar Cirebon karena menyadari akan pentingnya dokumentasi. Para fotografer diberi keleluasaan untuk memotret, menyajikan rincian-rincian gambar yang sesuai dengan berita untuk melengkapi sebuah naskah berita yang sudah diarahkan kepada wartawan dan fotografer. Menurut Dedi Haryadi wartawan Kriminal Surat Kabar Harian Umum Radar Cirebon:

“Meliput kejadian seperti kebakaran yang pertama di lakukan adalah datang ke lokasi kejadian memastikan info yang terjadi benar apa salah, mengambil gambar dengan segera saat peristiwa terjadi dan mencari data seperti mewawancarai saksi kejadian, dan pihak seperti pemadam kebakaran yang memadamkan api dengan bertanga sebab dari peristiwa terjadi, sampai akibat peristiwa tersebut."

Selanjutnya setelah seorang reporter/wartawan mendapatkan data dalam suatu peliputan, data tersebut diolah dalam kegiatan penulisan suatu berita. Penulisan berita biasanya menggunakan teknik melaporkan (to report), yang merujuk 
pada pola piramida terbalik (inverted pyramid), dan mengacu pada rumusan $5 \mathrm{~W}+1 \mathrm{H}$. Berita ditulis dengan menggunakan rumus $5 \mathrm{~W}+1 \mathrm{H}$, agar berita menjadi lengkap, akurat, dan sekaligus memenuhi standar teknis jurnalistik. Setiap peristiwa yang dilaporkan, harus terdapat enam unsur dasar, yaitu what (peristiwa apa yang akan dilaporkan kepada khalayak), who (siapa yang menjadi pelaku dalam peristiwa berita itu), when (kapan peristiwa itu terjadi), where (dimana peristiwa itu terjadi), why (mengapa peristiwa itu sampai terjadi), dan how (bagaimana jalannya peristiwa atau bagaimana cara menanggulangi peristiwa itu). Dalam konteks Indonesia, para praktisi jurnalistik kerap menambahkan satu unsur lagi yaitu aman (safety, S), sehingga rumusannya menjadi $5 \mathrm{~W}+1 \mathrm{H}$ (1S). Maksudnya, berita apa pun yang dipublikasikan, diyakini tidak akan menimbulkan dampak negatif bagi media massa bersangkutan dan masyarakat serta pemerintah.

Teknik melaporkan (to report), reporter atau wartawan Surat Kabar Harian Radar Cirebon tidak boleh memasukkan pendapat pribadi dalam berita yang ditulis. Berita adalah laporan tentang fakta secara apa adanya (das sain), bukan laporan tentang bagaimana seharusnya (das sollen). Reporter atau wartawan Radar Cirebon melaporkan liputan dengan menulisnya di ruang redaksi dengan data yang di dapat menggunakan bahasa yang lugas seperti dalam teknik piramida terbalik berarti pesan disusun secara deduktif. Kesimpulan dinyatakan terlebih dahulu pada paragraf pertama, kemudian disusul dengan penjelasan dan uraian yang lebih rinci pada paragrafparagraf berikutnya. Setelah pelaporan suatu liputan itu diketik oleh seorang reporter atau wartawan Surat Kabar Harian Umum Radar Cirebon naskah di kirim dengan menggunakan jaringan yang ada di komputer yang terhubung dengan redaktur, karena proses penyuntingan akan dilakukan.

Penyuntingan naskah atau editing adalah sebuah proses memperbaiki atau menyempurnakan tulisan secara redaksional dan substansial. Pelakunya disebut editor atau redaktur. Secara redaksional, editor memperbaiki kata dan kalimat supaya lebih logis, mudah dipahami, dan tidak rancu. Selain kata dan kalimat harus benar ejaan atau cara penulisannya, juga harus benar-benar mempunyai arti dan enak dibaca.

Sedangkan secara substansial, editor harus memperhatikan fakta dan data agar tetap terjaga keakuratan dan kebenarannya. Menurut redaktur Surat Kabar Harian Radar Cirebon Rusdi yang selaku Redaktur Pelaksana juga mengungkapkan:

"Penyuntingan dalam hal ini proses editor dilakukan seorang redaktur akan memeriksa setiap tulisan wartawan yang masuk untuk diedit secara keseluruhan, terutama penngambilan judul. Dalam penentuan judul suatu brita harus menarik dengan memperharikan angle berita yang diambil, judul harus mengandung unsur ketertarikan, agar pembaca lebih penasaran membaca suatu berita yang disajikan. Dari pengambilan judul yang menarik seorang pembaca penasan dengan isi yang di sajikan dalam berita, sehingga tulisan yang tersedia di kolom yang tersedia akan dibaca dengan detail".

Berita yang di terbitkan harus memperhatikan nilai, sehingga berita yang disajikan layak untuk diterbitkan. Dengan acuan standar nilai suatu berita. Surat Kabar Harian Umum Radar Ciebon pun mempunyai standar (alat ukur) berita yang layak untuk di terbitkan, Rusdi menjelaskan:

\begin{abstract}
“Aktualitas (Timeliness), semakin aktual sebuah berita akan semakin bagus dan menarik karna kejadian masih hangat di bicarakan, kedekatan (Proximity) kejadian sekitar Cirebon akan lebih di utamakan karena Surat Kabar Harian Umum Radar Cirebon mengedepankan berita lokal, keterkenalan (Prominence) yang diberitakan itu cukup dikenal khalayak massa, berita itu pun semakin menarik seperti tokoh-tokoh pemerintahan di wilayah Cirebon, dampak (Consequence); berita yang mempunyai dampak dalam nilai berita juga berperan penting, seperti kebijakan-kebijakan pemerintah yang di keluarkan untuk masyarakat, karena media perperan sebagai kontrol sosial, dan tentunya tidak ketinggalan berita yang mengandung unsur human interest seperti permasalahan sosial, lifestyle."
\end{abstract}

Tahap Penggerakan berikutnya erat kaitannya dengan pengarahan, Pengarahan disini erat kaitannya dengan tanggung jawab seorang kepala perusahaan terhadap para bawahannya. Fungsi menggerakkan tertuju pada karyawan untuk melaksanakan tanggung jawab mereka. Menurut Morissan fungsi pengarahan, ada empat komponen 
yang terkandung dalam fungsi pengarahan, yaitu: 1) Motivasi. Semakin tinggi tingkat kepuasan karyawan, maka karyawan memberikan kontribusi terbaiknya untuk mencapai tujuan. Dalam perjalanan panjangnya, pemimpin redaksi Harian Umum Radar Cirebon selalu berusaha memotivasi karyawannya agar bekerja lebih baik dan maksimal. Tidak hanya pemimpin redaksi, sesama karyawan satu dengan yang lain pun demikian. Bahkan dengan office boy sekalipun. Mereka saling memotivasi agar dapat memberikan yang terbaik untuk perusahaan;2) Komunikasi. Komunikasi adalah cara yang digunakan pimpinan agar karyawan mengetahui tujuan yang akan dicapai organisasinya. Dalam Harian Umum Radar Cirebon, karena motivasi dijalankan secara aktif baik dari pemimpin redaksi sampai staf tingkat bawah, maka komunikasi pun demikian. Pemimpin Redaksi Harian Umum Radar Cirebon Iing, selalu mengingatkan para stafnya. Begitu pun staf yang lain, juga saling mengingatkan dengan pendekatan komunikasi yang santun; 3) Kepemimpinan. Kepemimpinan merupakan kemampuan yang dimiliki seseorang untuk memengaruhi orang lain agar bekerja untuk mencapai tujuan. Menurut Stoner, kepemimpinan manajerial didefinisikan sebagai proses pengarahan pada kegitankegiatan dari sekelompok anggota yang saling berhubungan tugasnya. Dalam hal kepemimpinan, Iing selaku pemimpin redaksi mencoba untuk menjauhi gaya kepemimpinan yang kurang baik, karena akan menyebabkan karyawannya tidak nyaman; 4) Pelatihan. Pelatihan dalam suatu organisasi biasanya diberikan kepada karyawan yang baru lulus (fresh graduate) agar lebih menguasai teknik penyiaran dan visi misi media tersebut. Begitu pun dengan Harian Umum Radar Cirebon, pelatihan (training) untuk karyawan yang baru masuk dilaksanakan agar mereka paham betul akan visi dan misi Harian Umum Radar Cirebon. Selain itu, pelatihan atau berbagai workshop media cetak untuk meningkatkan kualitas Harian Umum Radar Cirebon agar lebih baik lagi selalu dilakukan untuk memberikan yang terbaik bagi khalayak setia Harian Umum Radar Cirebon.
Penggerakan dalam suatu media dilakukan secara berbeda-beda. Ada yang setiap kinerja terus menerus diarahkan, namun ada pula pengarahan tidak selalu dilaksanakan, namun tetap termonitor. Dalam hal ini, Harian Umum Radar Cirebon termasuk ciri yang kedua. Karena media ini tidak selalu memberikan pengarahan, namun dalam hal tertentu, misalnya perencanaan peliputan berita, maka pemimpin redaksi wajib mengarahi reporternya. Redaktur pun demikian, ia wajib memberikan pengarahan tentang bagaimana redaksi yang baik untuk proses peliputan berita berikutnya.

Fungsi pengarahan yang diterapkan pada Harian Umum Radar Cirebon, sudah termasuk ke dalam fungsi pengorganisasian. Artinya, fungsi penggerakan pun pada Harian Umum Radar Cirebon ditekankan pada reporter baru yang ingin menjadi reporter tetap Harian Umum Radar Cirebon untuk intens mengikuti masa training selama tiga bulan. Masa training ini digunakan untuk mengarahkan para reporter baru agar paham akan visi dan misi Harian Umum Radar Cirebon. Selebihnya, pengarahan terus dilakukan seiring pekerjaan itu sedang maupun akan dilaksanakan. Selain itu, masa training yang ditujukan untuk reporter baru, selain menjelaskan secara mengenai visi misi dan ideologi Harian Umum Radar Cirebon, juga akan dilatih bagaimana menyusun angle yang biasa diterapkan Harian Umum Radar Cirebon yaitu mengedepankan dan mengemas berita dari sisi permasalahan yang terjadi di Wilayah Cirebon, bagaimana menulis berita yang berimbang dan tidak berpihak, hingga berita siap terbit.

Pengarahan juga diterapkan saat rapat redaksi oleh pemimpin redaksi mengenai berita mana yang harus mereka liput, juga menyangkut angle mana yang harus ditentukan, dan mana yang harus diabaikan. Rapat redaksi ini juga ditentukan berapa reporter yang akan diutus dalam menghimpun berita. Jumlah yang diutus dalam meliput berita tergantung pada tingkat kesulitan peliputan dan besarnya event. Misalnya, jika berita Sea Games, maka yang diutus bisa mencapai tujuh sampai delapan reporter. Sedangkan untuk event yang tidak terlalu besar, cukup mengutus dua atau bahkan seorang saja. 
. Fungsi penggerakan pada media cetak juga ditekankan untuk para reporter baru, pengarahan itu bertujuan agar reporter baru itu tidak salah jalan dan tidak salah persepsi mengenai visi dan misi Harian Umum Radar Cirebon itu sendiri yang mengedepankan asas modern dan keprofesionalan. Pengarahan seperti di atas itu dirasa perlu menurut Rusdi sebagai kordinator lapangan Harian Umum Radar Cirebon:

“Karena tentunya, Harian Umum Radar Cirebon pasti berbeda dengan media lainnya yang tumbuh di Indonesia. Jika para reporter baru tidak diberikan pengetahuan secara dalam mengenai Harian Umum Radar Cirebon, ia pun akan salah langkah dan tak menutup kemungkinan akan membuat redaksi berita yang keluar dari sisi prinsip. Karena, selalu mengutamakan sisi menarik dalam setiap berita yang mereka tampilkan. Itulah satu alasan mengapa motto Harian Umum Radar Cirebon maju bersama Koran juara."

Artinya, informasi yang disajikan lebih diutamakan untuk masyarakat pantura dan Wilayah III Cirebon yang akan menyongsong era globalisasi dengan informasi yang terpercaya. Dari paparan di atas, dapat disimpulkan bahwa fungsi penggerakan pada Harian Umum Radar Cirebon sudah cukup baik sebab fungsi penggerakan tetap ada secara berkala. Namun pada intinya, pengarahan tetap dijalankan, khusus untuk reporter yang baru masuk untuk memperdalam pengetahuan mereka tentang Harian Umum Radar Cirebon, dan pengarahan terhadap proses peliputan berita tetap dilaksanakan agar produksi berita dapat dilakukan terus menerus dan tidak terhenti.

Begitu pun pengarahan bagi para staf yang bukan termasuk dalam tim redaksi, office boy misalnya. Mereka tetap diarahkan agar dapat bekerja dengan baik, maksimal dan perasaan yang ikhlas dan nyaman.

\section{Pengawasan}

Tahap pengawasan dalam manajemen redaksional adalah kegiatan untuk mengetahui apakah pelaksanaan kerja bidang redaksional telah sesuai dengan rencana semula atau tidak. Tahap pengawasan dalam bidang redaksional merupakan kegiatan penting karena adanya evaluasi dan penyuntingan hasil aktivitas sebuah berita yang akan diterbitkan. Pada tahap pengawasan hasil kerja bidang redaksional akan disesuaikan dengan konsep berita dan kriteria umum nilai berita yang berlaku universal.

Fungsi pengawasan dalam Harian Umum Radar Cirebon dilakukan oleh seluruh departemen. Dengan kata lain, seluruh staf memiliki tanggung jawab untuk mengawasi jalannya aktivitas pemberitaan sehari-hari, meskipun pengawasan yang vital dilaksanakan penuh oleh Kepala Bagian Marketing, Syahbana, untuk mengawasi jalannya periklanan, dan Pemimpin Redaksi Harian Umum Radar Cirebon Iing Casdirin untuk mengawasi seluruh kegiatan proses penyajian berita. Seperti yang telah diurai pada bab sebelumnya, pengawasan ialah suatu usaha sistematik untuk menetapkan standar pelaksanaan dengan tujuan-tujuan perencanaan, merancang system informasi umpan balik, membandingkan kegiatan nyata dengan standar yang telah ditetapkan sebelumnya, menentukan dan mengukur penyimpangan-penyimpangan serta mengambil tindakan koreksi yang diperlukan untuk menjamin bahwa semua sumber daya perusahaan digunakan dengan cara paling efektif dan efisien dalam pencapaian tujuan-tujuan perusahaan.

Pengawasan harus dilakukan berdasarkan hasil kerja atau kinerja yang dapat diukur agar fungsi pengawasan dapat berjalan secara efektif. Media cetak dapat tercermin dalam jumlah pembaca per hari yang mencakup komentar maupun bentuk komplain pembaca, berita tersebut juga dalam hal mengenai tingkat penjualan iklan, yang harganya tentu harus sesuai dengan keputusan bersama. Pengawasan terhadap jalannya kegiatan yang sudah terjadwal secara sistematis dalam sebuah media massa perlu diawasi oleh beberapa tim pengawas, atau pun seorang pengawas ahli. Pengawasan tersebut adakalanya dilaksanakan secara bersamaan, maupun dengan satu orang saja.

Pada hakikatnya, pengawasan dalam media massa sangatlah vital. Jika pengawasan itu tidak dilaksanakan, tentunya fungsi-fungsi yang lain tidak akan berjalan secara maksimal. Fungsi pengawasan sangatlah penting dalam keberadaan sebuah media massa. Karena dalam sebuah organisasi media massa, harus ada beberapa orang yang mengawasi jalannya kegiatan.Kegiatan menghimpun berita, kegiatan penerimaan iklan, pemberian kompenasi, penerimaan reporter dan pekerja baru, dan lain sebagainya yang berhubungan langsung dengan media massa. 
Begitu pula dengan fungsi Harian Umum Radar Cirebon. Fungsi manajemen dalam hal pengawasan pada Surat Kabar Harian Umum Radar Cirebon Menurut pemimpin Redaksi ling Casdirin:

"Mempunyai tujuan agar semua lini tetap on track, kerja sama tetap terjalin dengan baik, dan yang lebih utama, hubungan antar staf satu dengan lainnya tetap berhubungan baik. Fungsi pengawasan juga dilakukan oleh Kepala Bagian Operasional atau redaktur pelaksana Harian Umum Radar Cirebon dalam melayani masyarakat dan bisnis agar tidak berat sebelah. Artinya segala kegiatan yang dijalani harus proporsional."

Kegiatan pengawasan di atas tergambar pada penerimaan iklan yang telah penulis paparkan sebelumnya. Harian Umum Radar Cirebon mempunyai niatan yang sama yaitu agar semua kerja sama yang telah terjalin maupun akan terjalin tetap dapat diawasi dengan baik. Semua terlaksana secara proporsional dan seimbang, karena jika tidak seimbang maka akan terciptalah ketidakharmonisan dan fungsi pengawasan yang kurang baik. Fungsi pengawasan di sini dilakukan agar semua lini tetap on the track dan bisnis juga jalan. Jadi jangan sampai bisnis jalan tapi pemberitaan tidak. Fungsi pengawasan terbagi menjadi dua bagian, yaitu fungsi melayani dan fungsi bisnis. Fungsi melayani, karena Harian Umum Radar Cirebon ialah media massa penyampai informasi, sudah tentu Harian Umum Radar Cirebon harus melayani para pembacanya dengan baik berupa penyajian berita dengan bahasa sebaik mungkin dan tidak terkesan berpihak, mendengar masukan mereka, dan bersedia untuk berubah ke arah yang lebih baik jika itu keinginan khalayak pecintanya. Perubahan itu tercermin dari tampilan (layout) Harian Umum Radar Cirebon yang sudah berkali-kali menambah rubrik, karena selain ingin memenuhi keinginan masyarakat, Harian Umum Radar Cirebon juga tak ingin tertinggal dengan kecanggihan teknologi yang tengah terjadi. Itulah satu bentuk inovasi dari Harian Umum Radar Cirebon yang selalu ingin memenuhi keinginan pembacanya.

Selain itu Harian Umum Radar Cirebon pun memberikan kesempatan agar pembaca memberikan kritik dan sarannya guna perubahan bagi Harian Umum Radar Cirebon ke arah yang lebih baik. Secara perlahan namun pasti, semua saran itu diterima dan akan direalisasikan jika saran tersebut dapat membuat perubahan baik dari segi isi dan tampilan Harian Umum Radar Cirebon. Tentunya masukan dan kritik dari masyarakat itulah sangat berguna untuk Harian Umum Radar Cirebon dan kemudian diawasi secara berkesinambungan.

Harian Umum Radar Cirebon juga selalu mengawasi dalam kegiatan memproses berita, yaitu memproduksi berita, menyiarkan berita, dan mengevaluasi berita. Ketiga kegiatan tersebut terus dilakukan secara kontinyu agar tugas memproduksi berita tidak terhenti di tengah jalan. Pengawasan dalam kegiatan memproduksi berita, dipimpin oleh seorang redaktur karena ia adalah orang yang paling bertanggung jawab untuk isi berita secara keseluruhan.

Pemimpin Redaksi Surat Kabar Harian Radar Cirebn Iing Casdirin mengemukakan pengawasan dalam isi berita sangat penting yaitu:

"Kegiatan menyiarkan berita pun demikian harus secara keseluruhan mendapat pengawasan. Berita yang telah dikirim oleh reporter dan diedit oleh redaktur mereka tidak serta merta disiarkan. Masih banyak tingkatan lagi yang harus dipenuhi, yaitu penyeleksian berita. Kegiatan penyeleksian seputar berita mana yang layak dan tidak layak dipublikasikan tergantung pada redaktur Harian Umum Radar Cirebon."

Tiap berita yang telah siar dievaluasi lagi dan dicari apa kekurangannya. Hal ini terus dilakukan agar media ini makin berkualitas. Setelah berita selesai diseleksi, berita pun siap dipublikasikan untuk selanjutnya dibaca oleh khalayak luas. Pemublikasian berita tersebut selanjutnya akan dievaluasi mengenai apa saja kekurangannya. Angle mana yang kurang cocok, dan bagian mana untuk berita selanjutnya yang lebih ditonjolkan. Begitu seterusnya. Hal tersebut dilakukan agar menghasilkan isi berita Harian Umum Radar Cirebon yang berkualitas dan mampu menginformasikan kepada khalayak mengenai kejadian yang sebenarnya. Dalam pemberitaan isu atau pun kebijakan harus secara detail dan di kroscek kebenarannya, siapa yang menjadi sumber yang berkompeten dalam hal pemberitaan isu, pengemasan pesannya pun harus diperhatikan agar informasi yang tersampaikan tidak simpang siur. 
Fungsi bisnis pun harus mendapat pengawasan, Harian Umum Radar Cirebon mempertimbangkan kembali mengenai pengiklan yang masuk. Seperti yang telah dipaparkan penulis, jika iklan itu layak dijadikan partner kerja dan sesuai dengan visi, profesional dan modern yang diusung Harian Umum Radar Cirebon, iklan itu patut dipublikasikan.

Namun jika tidak, Harian Umum Radar Cirebon berhak menolaknya. Selain itu, persaingan media yang kian ketat menyebabkan Harian Umum Radar Cirebon berusaha untuk memperbagus tampilan dan isi berita. Karena persaingan itulah Harian Umum Radar Cirebon selalu mencoba menghadirkan sesuatu yang baru, berinovasi dan terus menyajikan berita yang layak baca. Namun, persaingan yang demikian pesat itu tidak serta merta menjadikan Harian Umum Radar Cirebon menghalalkan segala cara untuk mendapatkan pembaca yang banyak, Harian Umum Radar Cirebon tetap bersaing secara sehat dengan pesaing-pesaing media cetak lainnya yang juga turut melakukan berbagai inovasi.

Paparan di atas melukiskan bahwa fungsi pengawasan di Harian Umum Radar Cirebon telah tergolong baik karena tugas mengawasi dilakukan secara terus menerus. Kepala bagian marketing mengawasi jalannya kegiatan pasokan iklan yang hendak bekerja sama dengan Harian Umum Radar Cirebon. Sedangkan bagian redaksi, lebih tepatnya kepala bagian redaksi juga turut mengawasi jalannya proses peliputan berita, pengiriman berita, redaksi bahasa berita (menyunting naskah dari para reporter maupun berita yang didapat dari beberapa kantor berita dunia semisal Jawa pos, AFP, AP, REUTERS). Hal ini dilakukan agar bagaimana berita dapat dibaca dan dimengerti dengan baik hingga akhirnya berita siap akses, sehingga khalayak dapat segera mengetahui informasi terbaru.

Pengembangan pasti dilakukan oleh tiap media massa dengan cara yang berbeda. Begitu pula dengan Surat Kabar Harian Umum Radar Cirebon . Surat Kabar Harian Umum Radar Cirebon selalu berinovasi karena kita media Cetak. Kita juga selalu mengikuti perkembangan. Surat Kabar Harian Umum Radar Cirebon selalu berusaha memberikan inovasi pengembangan tampilan dan pengembangan staf. Berangkat dari statemen tersebut, dapat disimpulkan bahwa fungsi pengembangan yang diterapkan pada Surat Kabar Harian Umum Radar Cirebon terdiri atas dua bagian yaitu pengembangan dalam bentuk content (isi) dan pengembangan staf.

Untuk pengembangan dalam bentuk content (isi), Surat Kabar Harian Umum Radar Cirebon melakukan berbagai perubahan dalam isi rubrik seperti penambahan rubrik yang bernuansa life style, pengembangan dalam isi berita, dan evaluasi berita yang telah dibuat.

Dalam perkembangannya Surat Kabar Harian Umum Radar Cirebon juga selalu mendengar keluhan dan permintaan pencintanya. Sebagai media cetak yang telah dapat mempertahankan eksistensinya selama belasan tahun, Surat Kabar Harian Umum Radar Cirebon juga terus melakukan pengembangan untuk para stafnya. Beberapa di antaranya untuk mengikuti workshop mengenai perkembangan media cetak. Dari paparan di atas, dapat disimpulkan bahwa fungsi pengembangan pada Surat Kabar Harian Umum Radar Cirebon sudah tergolong bagus. Karena, pengembangan tampilan isi dan pengembangan para staf terus dilakukan. Pengembangan sangat penting dilakukan untuk meningkatkan rasa kepercayaan masyarakat terhadap produk berita Surat Kabar Harian Umum Radar Cirebon, mengingat pembaca tak hanya dari kalangan domestik wilyah pantura dan wilayah III Cirebon, juga meningkatkan jumlah pembaca sehingga mereka tidak merasa bosan dan monoton jika informasi dan tampilan yang disajikan Surat Kabar Harian Umum Radar Cirebon tanpa sebuah inovasi berarti.

Setiap perusahaan idealnya sangat menginginkan kesejahteraan bagi para stafnya. Tujuan itu berfungsi agar para staf merasa kerasan, tidak beralih ke perusahaan lain, dan memiliki sense of belonging yang tinggi. Bentuk kesejahteraan itu tercermin dari besarnya kompensasi yang didapat dari para staf dalam perusahaan tersebut. Namun, besar kecilnya kompensasi biasanya dipengaruhi oleh beberapa komponen, salah satunya tingkat kedisiplinan staf itu sendiri. Tingkat kedisiplinan itu akan dinilai dan nantinya akan diperhitungkan berapa kompensasi yang diperoleh. Begitu pun dengan Surat Kabar Harian Umum Radar Cirebon bahwa kompensasi adalah seluruh imbalan 
yang diterima karyawan atas hasil kerja karyawan tersebut pada organisasi. Kompensasi bisa berupa fisik maupun non fisik dan harus dihitung dan diberikan kepada karyawan sesuai dengan pengorbanan yang telah diberikannya kepada perusahaan tempat ia bekerja. Perusahaan dalam memberikan kompensasi kepada para pekerja terlebih dahulu melakukan penghitungan kinerja dengan membuat sistem penilaian kinerja yang adil dalam hal ini pun pengawasan terhadap karyawan perlu dilakukan. Sistem tersebut umumnya berisi criteria penilaian setiap pegawai.

\section{Simpulan}

Sebuah perusahaan media tentunya ingin selalu mempertahankan eksistensi mereka dalam dunia penyajian informasi yang baik, berimbang dan tidak berpihak. Untuk mencapai target tersebut, ada beberapa cara yang harus ditempuh. Maka penulis dapat menarik kesimpulan sebagai berikut: 1) Pada tahap perencanaan yang ada di bidang redaksional Surat Kabar Harian Umum Radar Cirebon telah terencana dengan baik, hal ini terlihat dari terlaksananya rapat perencanaan liputan atau rapat redaksi. Secara garis besar, dalam rapat tersebut menyangkut dua hal, yaitu penentuan liputan dan pembagian tugas para wartawan dalam meliput berita; 2) Pada tahap pengorganisasian manajemen redaksional Surat Kabar Harian Umum Radar Cirebon, telah terbentuk struktur organisasi dengan jabatan dan tugas masing-masing personil. Dalam proses pengelolaan materi pemberitaan, yang paling berperan di bidang redaksional Surat Kabar Harian Umum Radar Cirebon adalah pemimpin redaksi, hal ini terlihat dari tugas pemimpin redaksi yang merangkap menjadi redaktur; 3) Tahap penggerakan merupakan tahap yang sangat penting dalam manajemen redaksional di Surat Kabar Harian Umum Radar Cirebon, karena dengan adanya penggerakan, proses pengelolaan materi pemberitaan berjalan dengan lancar, mulai dari proses peliputan, penulisan, sampai pada penyuntingan (editing) naskah berita. Dalam hal ini tidak terlepas dari adanya fasilitas yang telah disediakan oleh perusahaan, adanya pengarahan dari pemimpin redaksi dan coordinator peliputan, dan terjalinnya komunikasi antar staf bidang redaksional dalam menjalankan tugas keredaksionalan; 4) Tahap pengawasan dalam manajemen redaksional pada Surat Kabar Harian Umum Radar Cirebon dilakukan dalam bentuk pengarahan langsung terhadap wartawan saat naskah beritanya diedit oleh redaktur masih mengalami kekurangan data. Selain itu, diadakan pertemuan-pertemuan seperti rapat evaluasi kerja. Dalam rapat tersebut, juga membahas masalah-masalah yang dihadapi oleh bidang redaksional dan kendala-kendala yang dialami oleh wartawan dalam melaksanakan tugas, sehingga akan dibahas dan dicarikan solusinya. Selanjutnya pemimpin umum mengeluarkan kebijakankebijakan yang terkait dengan kelancaran proses redaksional.

Setelah meneliti dan menganalisis data mengenai manajemen redaksional pada Surat Kabar Harian Umum Radar Cirebon, penulis ingin memberikan saran sebagai bahan pertimbangan dalam pengambilan kebijakan manajemen redaksional Surat Kabar Harian Umum Radar Cirebon, antara lain adalah: 1). Dalam hal perwajahan, sebaiknya pembaharuan agar lebih variatif, dalam hal ini penambahan rurik yang menaik menjadi unsur yang perlu diperhatikan, selain beritaberita peristiwa dan isu, masalah human interest juga perlu di tingkatkan untuk menambah rubrik baru yang menarik sehingga perwajahan lebih bervariatit dan beragam; 2) Untuk masalah kuantitas tim redaksi, sebaiknya tim redaksi Surat Kabar Harian Umum Radar Cirebon ditambah jumlahnya. Sebab, tim redaksi yang lebih banyak memungkinkan akan terlaksananya penerapan fungsi manajemen redaksi pada Surat Kabar Harian Umum Radar Cirebon yang lebih baik lagi, dalam hal ini redaktur fokus untuk membawahi desk masing-masing tidak tercabang menangani desk suatu rubrik berita; 3) Terakhir, dalam hal kepemimpinan, sudah cukup baik, namun akan lebih baik lagi jika pemimpin redaksi Surat Kabar Harian Umum Radar Cirebon dapat lebih tegas namun tetap santun dalam mengarahkan para stafnya. Pergantian pemimpin redaksi juga nampaknya ditentukan berapa tahun sekali untuk peningkatan kualitas dan pengembangan Surat Kabar Harian Umum Radar Cirebon di masa yang akan datang; 4) Perlunya peningkatan evaluasi kualitas dan kuantitas, baik dari segi materi pemberitaan 
maupun kerja dari masing-masing personil di bidang redaksional, dan menerapkan kedisiplinan dalam menjalankan tugas keredaksionalan.

\section{Daftar Pustaka}

Alwi, Fuadi M. (2004). Foto Jurnalistik. Jakarta: PT. Bumi Aksara.

Amsyah, Zulkifli. (2005). Manajemen Sistem Informasi. Jakarta: PT. Gramedia Pustaka Utama.

Djuroto, Totok. (2006). Manajemen Penerbitan Pers, cet. III. Bandung: PT. Remaja Rosdakarya.

Effendy, Onong Uchjana. (1993). Human Relations dan Public Relations. Bandung: Mandar Maju.

Effendy, Onong U. (2000). Dinamika Komunikasi. Bandung: PT Remaja Rosdakarya.

Effendy, Onong U. (2002). Ilmu Komunikasi, Teori dan Praktek, Bandung: PT Remaja Rosdakarya.

Effendy, M. Manullah. (2002). Dasar-dasar Manajemen. Jakarta: Ghalia Indonesia.

Eko Indrajit, Richardus. (2001). Pengantar Konsep Dasar Manajemen Sistem Informasi dan Teknologi Informasi. Jakarta: Elex Media Komputindo.

Hasibuan, Malayu. (2005). Manajemen Dasar, Pengertian dan Masalah. Jakarta: Bumi Aksara

Herujito, Yayat. (2001). Dasar-Dasar Manajemen. Jakarta: PT. Grasindo.

Kriyantono, Rachmat. (2006). Teknik Praktis Riset Komunikasi. Jakarta: Kencana Media.

Kusumaningrat, Hikmat. (2006). Jurnalistik Teori dan Praktik. Bandung: PT. Remaja Rosdakarya.

M. Romli, Asep Samsul. (2005). Jurnalistik Praktis, cet VI. Bandung: Remaja Rosdakarya.

Masduki. (2005). Kebebasan Pers dan Kode Etik Jurnalistik. Jakarta: UII Press.

Maleong, Lexy. (2007). Metodologi Penelitian Kualitatif. Bandung: Remaja Rosdakarya.

McQuail, Dennis. (1996). Teori Komunikasi Massa. Bandung: Erlangga.

Morissan. (2005). Media Penyiaran; Strategi Mengelola Radio dan Televisi. Jakarta: PT. Ramdina Prakarsa.

Mubardjo. (2008). Strategi Manajemen Media Cetak. Jakarta: PT. Duta Karya Swasta.
Mumford, Alan. (2003). Mencetak Manajer Andal Melalui Coaching dan Monitoring. Jakarta: PT. Pustaka.

Rakhmat, Jalaluddin. (2001). Metode Penelitian Komunikasi. Bandung: PT. Remaja Rosdakarya.

Ruslan, Rosady. (2005). Manajemen Public Relations $\mathcal{E} \quad M e d i a$ Komunikasi.Bandung: Rosdakarya.

Santana, Septiawan. (2005). Jurnalisme Kontemporer. Jakarta: Yayasan Obor.

Siagian, Sondang. (2006). Sistem Informasi Manajemen. Jakarta: Bumi Aksara.

Syamsul M. Romli, Asep. 2005. Jurnalistik Praktis. Bandung. Remaja Rosdakarya.

Tebba, Sudirman. (2005). Jurnalistik Baru. Jakarta: Kalam Indonesia.

\section{Kamus}

Departemen Pendidikan dan Kebudayaan. 2000. Kamus Besar Bahasa Indonesia. Jakarta. Balai Pustaka.

\section{Publikasi Tidak Diterbitkan}

Profil Company Surat Kabar Harian Umum Radar Cirebon

\section{Peraturan Perundangan}

Undang-undang Republik Indonesia tahun 1999 No 40 tentang Pers.

\section{Sumber Internet}

$\mathrm{S} \mathrm{t}$ e $\mathrm{f} \mathrm{a} \mathrm{n} \mathrm{u} \mathrm{s} \quad$ A k i m, http:/ / stefanusakim.multiply.com/ journal/item/19/manajemen keredaksian, di akses pada 19 April 2013 21:32:36 